\title{
BUDAYA MAMFATIN UKUNRAI SEBAGAI PARADOKS PARTISIPASI MASYARAKAT DALAM PERENCANAAN PEMBANGUNAN DESA
}

\author{
Donna Isra Silaban ${ }^{1}$, Imelda Nahak ${ }^{2}$ \\ ${ }^{1,2}$ Fakultas Komunikasi dan Desain, Universitas Informatika dan Bisnis Indonesia \\ Email : donnaisra@unibi.ac.id ${ }^{1}$ nahak.imelda@gmail.com²
}

\begin{abstract}
Abstrak
Studi ini bertujuan untuk mengkaji komunikasi pembangunan dalam partisipasi masyarakat pada perencanaan pembangunan desa. Partisipasi masyarakat sangat penting karena bisa menjamin efektivitas program pembangunan. Dalam praktiknya, terdapat sejumlah kendala partisipasi masyarakat dalam perencanaan pembangunan. Beberapa kendala yang berhasil diidentifikasi, yaitu tidak adanya dukungan hukum (Rumensten, 2012), kurangnya kesadaran masyarakat, rendahnya kualitas SDM, lama tinggal dan jenis pekerjaan yang menyita waktu luang (Wijaksono, 2013), kurangnya sosialisasi dari pemerintah (Sagita, 2016), kemiskinan dan keterbatasan akses yang diberikan pemerintah (Ompusunggu, 2017), dan adanya kepentingan birokrasi (Mbeche, 2017). Studi-studi tersebut mempertimbangkan faktor budaya yang menyebabkan rendahnya partisipasi masyarakat. Studi kasus kualitatif ini memperluas studi-studi sebelumnya dengan mengungkap budaya mamfatin ukunrai yang mendorong rendahnya partisipasi masyarakat dalam perencanaan pembangunan di Desa Naran (samaran) Kecamatan Raimanuk Kabupaten Belu. Budaya mamfatin ukunrai merupakan kebiasaan masyarakat yang menganggap perencanaan pembangunan sebagai tugas dan tanggung jawab pemerintah. Masyarakat hanya berperan sebagai pelaksana program pembangunan yang ditetapkan pemerintah.
\end{abstract}

Kata Kunci : komunikasi pembangunan, budaya , perencanaan pembangunan

\begin{abstract}
This study aims to examine development communication in community participation in village development planning. Community participation is very important because it can guarantee the effectiveness of development programs. There are a number of obstacles to community participation in development planning. Some identified barriers are the absence of legal support (Rumensten, 2012), lack of public awareness, low quality of human resources, length of stay and hours employment type (Wijaksono, 2013), lack of socialization from the government (Sagita, 2016), poverty and limited access provided by the government (Ompusunggu, 2017), and interest of bureaucracy in planning (Mbeche, 2017). These studies, indeed, have not considered yet cultural factor leading to disinvolvement. This qualitative case study extends previous studies by revealing the culture of mamfatin ukunrai discouraging community participation in development planning in Naran Village (pseudonym), Raimanuk Subdistrict, Belu Regency. Mamfatin ukunrai is a custom considering development planning is government's duties and responsibilities. Villagers are merely the executor of development programs. This custom is a legacy of royal government system and dominates the mindset of villagers. The tradition of highly appreciating the government unwittingly creates an invisible distance between government and society. It has discouraged villagers' participation.
\end{abstract}

Keyword: development communication, culture, development planning 


\section{PENDAHULUAN}

Partisipasi masyarakat dalam perencanaan pembangunan telah menjadi topik kajian penting dan menjadi salah satu trend dalam penelitian ilmiah sejak tahun 2000. Pentingnya partisipasi masyarakat berkaitan dengan efektivitas dan efisiensi pemenuhan kebutuhan masyarakat, yang bertujuan untuk mewujudkan kehidupan masyarakat yang adil dan sejahtera. Partisipasi masyarakat mencakup empat hal, yakni: "1) Penerimaan manfaat bagi masing-masing orang yang berpartisipasi, 2) Partisipasi masyarakat mencerminkan kebutuhan mendasar dan nilai-nilai kebaikan bagi manusia, 3) Partisipasi masyarakat adalah jaminan bagi terpenuhinya kebutuhan, dan 4) Partisipasi menghasilkan pengambilan keputusan yang tepat dalam pelaksanaan pembangunan (Rostam, Ansari, \& Vinejad, 2018). Selanjutnya, Ali menegaskan bahwa partisipasi masyarakat merupakan salah satu elemen penting pembangunan karena dapat mempermudah mobilisasi sumber daya lokal, membuka kesempatan kerja dan melatih masyarakat untuk lebih bersikap kreatif dengan keturutsertaannya dalam proses pembangunan (Ngindana dan Hanafi, 2012:29-30). Dengan demikian, partisipasi masyarakat juga dapat memberdayakan masyarakat (Al-Kautsari, 2017; Alyas, 2015; Atmojo, Eko, Fridayani, Kasiwi, \& Pratama, 2017; Defina, 2012; Fitriani, Selinaswati, \& Mardiah, 2017).

Partisipasi masyarakat mulai mendapat perhatian dari pemerintah sejak tahun 1999, sejak diterapkannya sistem politik demokrasi dan sistem pemerintahan daerah. Berbagai ketentuan hukum pun dibuat untuk memastikan terlaksananya pembangunan yang partisipatif, di antaranya UU No.22 tahun 1999, UU No.32 tahun 2004, UU No.23 tahun 2014 tentang pemerintahan daerah, UU No.4 tahun 2014 tentang Desa, Permendagri No.114 tahun 2014 tentang Pedoman
Pembangunan Desa, dan Permendagri No.20 tahun 2018 tentang Pengelolaan Keuangan Desa. Namun, alasan-alasan yang membuat partisipasi masyarakat menjadi penting disamping keberadaan hukum sebagai pendukung ternyata belum menjamin terlaksananya partisipasi masyarakat dalam pelaksanaan pembangunan.

Studi yang dilakukan oleh Marzuki (2009) terhadap partisipasi masyarakat dalam analisis mengenai dampak lingkungan di Malaysia menyebutkan partisipasi masyarakat masih terbatas pada pihak yang menyediakan informasi untuk meningkatkan kualitas laporan AMDAL. Masalah-masalah sosial yang ada di dalam masyarakat cenderung diabaikan karena masyarakat tidak dilibatkan dalam proses pengambilan keputusan. Rumensten (2012) melakukan studi lainnya dan menjelaskan bahwa partisipasi masyarakat dalam pembentukan peraturan daerah masih rendah karena keberadaan hukum yang kurang mengikat. Studi lainnya yang dilakukan di Tanggerang lebih melihat pada sisi masyarakat, yang mana rendahnya partisipasi masyarakat dalam menyikapi perubahan fungsi lahan disebabkan oleh kurangnya kesadaran, rendahnya SDM masyarakat, pengaruh lama tinggal dan pola yang menyebabkan tidak adanya waktu luang untuk berpartisipasi (Wijaksono, 2013). Selain itu, kurangnya sosialisasi dari pemerintah terkait program yang dilaksanakan merupakan faktor lainnya yang menyebabkan partisipasi masyarakat menjadi rendah (Sagita, 2016).

Ompusunggu (2017) melakukan studi terhadap partisipasi masyarakat dalam pembangunan irigasi di Desa Namo Bintang Kecamatan Pancur Batu. Hasil penelitiannya menunjukkan bahwa faktor kemiskinan dan keterbatasan akses dari pemerintah merupakan penyebab rendahnya partisipasi masyarakat. Mbeche 
(2017) dalam penelitiannya terhadap partisipasi masyarakat dalam perencanaan untuk mengurangi gas emisi akibat penggundulan dan degradasi hutan menyebut ketiadaan partisipasi masyarakat ini sebagai 'partisipasi simbolis'. Meskipun ketentuan mengharuskan semua pemangku kepentingan terlibat dalam menyusun perencanaan, partisipasi masyarakat lokal menjadi simbol belaka ketika penyusunan perencanaannya hanya melibatkan orang-orang tertentu sebagai perwakilan masyarakat atau yang disebut 'perwakilan substantif'.

Studi peneliti di Desa Naran menemukan hal baru dari segi kebudayaan lokal yang menyebabkan rendahnya partisipasi masyarakat dalam perencanaan pembangunan. Kebudayaan tersebut bersumber pada kebiasaan yang diwariskan secara tak langsung dan tak jelas namun mampu mempengaruhi pola pikir sebagian besar masyarakat sehingga menimbulkan sikap enggan untuk berpartisipasi dalam perencanaan pembangunan desa. Peneliti menyebut kebiasaan tersebut sebagai budaya mamfatin ukunrai. Budaya mamfatin ukunrai merujuk pada kebiasaan masyarakat yang menganggap segala urusan yang berkaitan dengan pengelolaan pemerintahan merupakan tugas pemerintah, bukan tugas masyarakat. Dengan demikian, masyarakat tidak mempunyai suatu keharusan untuk turut mengambil bagian dalam pengelolaan pemerintahan, termasuk perencanaan pembangunan desa. Untuk mencari tahu lebih lanjut, peneliti kemudian melakukan penelitian terhadap partisipasi masyarakat dalam perencanaan pembangunan, untuk menggali lebih dalam tentang kondisi partisipasi masyarakat dan budaya mamfatin ukunrai di Desa Naran Kecamatan Raimanuk Kabupaten Belu.

\section{KAJIAN PUSTAKA}

2.1 Kondisi Partisipasi Masyarakat Dalam Perencanaan Pembangunan Di Desa Naran

Pembangunan merupakan serangkaian usaha yang dilakukan secara sadar dan berencana serta berkelanjutan oleh suatu bangsa dengan harapan membawa perubahan dan pertumbuhan guna mempercepat modernisasi kehidupan bangsa untuk pencapaian tujuan akhir bangsa tersebut. Aspek-aspek pembangunan telah mengalami perubahan sejak komunikasi pembangunan mulai dikenal di Indonesia pada awal 1970-an baik dalam organisasi strategi penanggulangan kemiskinan maupun penggunaan media komunikasi (Agusta, 2007).

Dalam kaitannya dengan pembangunan nasional dewasa ini, pemerintah telah menitik beratkan pada usaha meningkatkan aktivitas pembangunan di sektor pedesaan yang mempunyai nilai strategis dalam konteks pembangunan nasional. Hal ini dikarenakan sebagian besar $(80 \%)$ penduduk Indonesia pada kenyataannya bermukim di pedesaan yang merupakan potensi yang tinggi untuk sumber daya manusia dan sumber-sumber kekayaan alam (Gumilar, 2008). Oleh karena itu, pembangunan perdesaan merupakan bagian yang penting dan tidak terpisahkan dari pembangunan nasional, sehingga pembangunan Daerah Tingkat I meletakkan kerangka bagi bangsa Indonesia untuk tumbuh dan berkembang di atas kemampuan sendiri.

Masyarakat perdesaan hidup dengan berbagai latar belakang tradisi yang memiliki nilai-nilai sosial tertentu yang di antara nilai sosial tersebut bersifat kurang menunjang. Hal ini merupakan tantangan pelaku pembangunan nasional dalamupaya membangun masyarakat secara menyeluruh tanpamenimbukan jurang komunikasi antara pemerintah dan masyarakat. Bagi pembangunan pertanian, tingkat pendidikan petani yang rendah merupakan salah satu permasalahan yang 


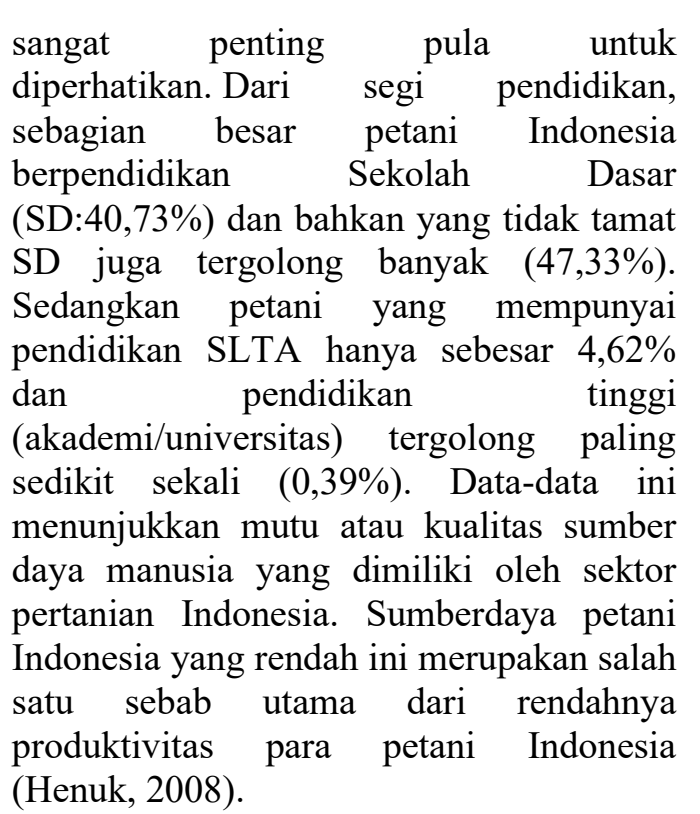

Keberhasilan pembangunan tidak hanya bergantung pada tersedianya prasarana material tetapi juga bergantung pada tersedianya prasarana moral yaitu peraturan tata tertib dan sikap mental serta adat kebiasaan yang bersifat positif dan favourable yaitu berupa pandangan yang dapat sejalan dan memberikan dorongan kepada berhasilnya suatu pembangunan. Oleh karena itu, usaha untuk mengubah sikap mental masyarakat dari sikap yang cenderung kurang mendukung sehingga dapat menerima konsepsi-konsepsi pandangan yang bersifat dinamis dan maju perlu dilaksanakan. Keterlibatan berbagai pihak, baik dari manusia penggeraknya dengan sarana dan prasarana yang tersedia seperti potensi alam nilai budaya dan juga kesediaan masyarakat yang ingin dibangun. Sebaliknya kemampuan mempengaruhi dan menggerakkan potensipotensi yang tersedia akan mendorong kesadaran masyarakat untuk lebih aktif dalam kegiatan pembangunan.

Konsep komunikasi pembangunan dapat dilihat dalam arti luas dan arti sempit. Dalam arti luas, komunikasi pembangunan meliputi peran dan fungsi komunikasi (sebagai suatu aktivitas pertukaran pesan secara timbal balik) di antara semua pihak yang terlibat dalam usaha pembangunan; terutama antara masyarakat dengan pemerintah, sejak dari proses perencanaan, kemudian pelaksanaan, dan penilaian terhadap pembangunan. Dalam arti sempit, komunikasi pembangunan merupakan segala upaya dan cara, serta teknik penyampaian gagasan, dan keterampilanketerampilan pembangunan yang berasal dari pihak yang memprakarsai pembangunan dan ditujukan kepada masyarakat luas. Kegiatan tersebut bertujuan agar masyarakat yang dituju dapat memahami, menerima, dan berpartisipasi dalam melaksanakan gagasan-gagasan yang disampaikan (Gumilar, 2008).

Dalam karyanya, Schramm (1964) merumuskan tugas pokok komunikasi dalam suatu perubahan sosial untuk pembangunan nasional, yaitu:

1. Menyampaikan informasi tentang pembangunan nasional kepada masyarakat agar dapat memusatkan perhatian pada kebutuhan akan perubahan, kesempatan dan cara mengadakan perubahan, saranasarana perubahan, dan membangkitkan aspirasi nasional.

2. Memberikan kesempatan kepada masyarakat untuk mengambil bagian secara aktif dalam proses pembuatan keputusan, memperluas dialog agar melibatkan semua pihak yang membuat keputusan mengenai perubahan, memberi kesempatan kepada para pemimpin masyarakat untuk memimpin dan mendengarkan pendapat rakyat kecil, serta menciptakan arus informasi yang berjalan lancar dari bawah ke atas.

3. Mendidik tenaga kerja yang diperlukan dalam pembangunan yang mendukung proses untuk mengubah hidup masyarakat.

Norton et al. (2006) menyatakan bahwa dalam rangkaian komunikasi pembangunan pertanian dan perdesaan saat ini membutuhkan sistem penelitian yang berkaitan dengan lembaga lingkup internal maupun eksternal yang mampu menghasilkan teknologi tepat guna (teknologi yang mampu memecahkan permasalahan terhadap isu yang berkembang di dunia saat ini), yaitu: jumlah dan pertumbuhan penduduk, kemiskinan, kebutuhan energi, ketahanan 
pangan, degradasi lingkungan dan perubahan iklim); menyaring, menyesuaikan, dan memproduksi teknologi dan lembaga baru; serta melakukan baik uji coba di stasiun (lahan terbatas) maupun di lahan usaha tani.

Partisipasi masyarakat merupakan kebutuhan mutlak dalam perencanaan pembangunan, terutama di wilayah pedesaan. Sebagai wilayah pemerintahan terkecil, keberhasilan pembangunan di desa berarti keberhasilan membangun masyarakat dari komunitas akar rumput. Untuk itu, melalui UU No.6 Tahun 2014 tentang Desa, UU No.23 tahun 2014 tentang Pemerintah Daerah, Permendagri No.114 tahun 2014 tentang Pedoman Pembangunan Desa dan Permendagri No.20 tahun 2018 tentang Pengelolaan Keuangan Desa, pemerintah berupaya menegaskan bahwa partisipasi masyarakat itu penting dalam pengelolaan pemerintahan desa. Bahkan dalam Permendagri No. 114 tahun 2014, dipaparkan secara rinci mengenai tahapantahapan proses yang harus dilalui dalam melaksanakan pembangunan desa. Meskipun demikian, partisipasi masyarakat dalam perencanaan pembangunan di Desa Naran sangat rendah. Berdasarkan hasil studi peneliti terhadap daftar hadir kegiatan pengkajian keadaan desa (PKD) tahun 2017 dan foto kegiatan musyawarah desa (musdes) tahun 2018, dari 631 rumah tangga yang ada, hanya $35 \%$ yang hadir dalam PKD tahun 2017 dan $38 \%$ dalam musdes tahun 2018. Untuk lebih jelasnya dapat dilihat pada tabel berikut :

Tabel 1.1 Rekapan Kehadiran Masyarakat dalam PKD T.A. 2017 dan Musdus T.A 2018

Sumber : Dokumen Perencanaan Hasil Musdus dan PKD T.A 2017 Desa Naran dan foto kegiatan musdus T.A 2019

\begin{tabular}{|c|c|c|c|c|c|c|}
\hline \multirow[t]{2}{*}{ No } & \multirow[t]{2}{*}{ Dusun } & \multirow[t]{2}{*}{$\begin{array}{c}\text { Jumlah } \\
\text { KK }\end{array}$} & \multicolumn{2}{|c|}{ Kehadiran } & \multicolumn{2}{|c|}{$\begin{array}{c}\text { Persentase } \\
\text { Hadir }\end{array}$} \\
\hline & & & 2018 & 2019 & 2018 & 2019 \\
\hline 1 & $\begin{array}{l}\text { Aimalae } \\
\text { (Samaran) }\end{array}$ & 49 & 18 & 15 & $\begin{array}{l}37 \\
\%\end{array}$ & $\begin{array}{l}37 \\
\%\end{array}$ \\
\hline 2 & $\begin{array}{l}\text { Amea } \\
\text { (Samaran) }\end{array}$ & 65 & 18 & 25 & $\begin{array}{l}28 \\
\%\end{array}$ & $\begin{array}{l}38 \\
\%\end{array}$ \\
\hline 3 & $\begin{array}{l}\text { Anaoloro } \\
\text { A } \\
\text { (Samaran) }\end{array}$ & 45 & 16 & 21 & $\begin{array}{l}36 \\
\%\end{array}$ & $\begin{array}{l}47 \\
\%\end{array}$ \\
\hline 4 & $\begin{array}{l}\text { Anaoloro } \\
\text { B } \\
\text { (Samaran) }\end{array}$ & 48 & 15 & 25 & $\begin{array}{l}31 \\
\%\end{array}$ & $\begin{array}{l}52 \\
\%\end{array}$ \\
\hline 5 & $\begin{array}{l}\text { Kota Ikun } \\
\text { (Samaran) }\end{array}$ & 61 & 28 & 17 & $\begin{array}{l}46 \\
\%\end{array}$ & $\begin{array}{l}28 \\
\%\end{array}$ \\
\hline 6 & $\begin{array}{l}\text { Motamauk } \\
\text { (Samaran) }\end{array}$ & 85 & 14 & 17 & $\begin{array}{l}16 \\
\%\end{array}$ & $\begin{array}{l}20 \\
\%\end{array}$ \\
\hline 7 & $\begin{array}{l}\text { Subaru } \\
\text { (Samaran) }\end{array}$ & 34 & 16 & 13 & $\begin{array}{l}47 \\
\%\end{array}$ & $\begin{array}{l}38 \\
\%\end{array}$ \\
\hline 8 & $\begin{array}{l}\text { Talerun } \\
\text { (Samaran) }\end{array}$ & 38 & 14 & 16 & $\begin{array}{l}37 \\
\%\end{array}$ & $\begin{array}{l}42 \\
\%\end{array}$ \\
\hline 9 & $\begin{array}{l}\text { Tukunu } \\
\text { (Samaran) }\end{array}$ & 45 & 21 & 17 & $\begin{array}{l}47 \\
\%\end{array}$ & $\begin{array}{l}38 \\
\%\end{array}$ \\
\hline 10 & $\begin{array}{l}\text { Umabedua } \\
\text { A } \\
\text { (Samaran) }\end{array}$ & 49 & 20 & 29 & $\begin{array}{l}41 \\
\%\end{array}$ & $\begin{array}{l}59 \\
\%\end{array}$ \\
\hline 11 & Umabedua & 74 & 18 & 34 & 24 & 46 \\
\hline
\end{tabular}




\begin{tabular}{cllllll}
\hline \multicolumn{1}{c}{ B } & & & & $\%$ & $\%$ \\
\hline 12 & (Samaran) & & & & & \\
\hline Wekrame & 38 & 20 & 13 & 53 & 34 \\
(Samaran) & & & & $\%$ & $\%$ \\
\hline JUMLAH & 631 & 218 & 242 & & \\
\hline
\end{tabular}

Tabel 1.1 menunjukkan bahwa pada tahun 2017, hanya 1 dari 12 dusun yang jumlah kehadiran masyarakatnya mencapai $50 \%$, sedangkan pada tahun 2018 , hanya 2 dusun yang kehadirannya mencapai $50 \%$. Dusun Motamauk dengan jumlah KK terbanyak justru menduduki urutan terendah selama dua tahun berturut-turut. Hadir atau tidaknya masyarakat dalam perencanaan pembangunan desa tergantung pada diundang atau tidaknya mereka dalam kegiatan yang dimaksud. Seluruh informan dalam penelitian ini menjelaskan bahwa dalam tahun-tahun sebelum tahun 2018, masyarakat tidak pernah dilibatkan secara langsung dalam PKD, musdus, musdes maupun musrenbangdes. Hal ini dikarenakan pemerintah lebih cenderung mempercayakan kepentingan masyarakat kepada BPD, kepala dusun, RW, RT dan tokoh masyarakat yang diyakini dapat memperjuangkan kebutuhan masyarakat. Penyelenggaraan musyawarah secara terbuka baru dilaksanakan pada akhir tahun 2018. Namun, jumlah kehadiran masyarakat tidak mengalami peningkatan yang signifikan, yakni hanya sebanyak 3 $\%$. Sehingga dapat dikatakan bahwa partisipasi masyarakat dalam perencanaan pembangunan di Desa Naran sejak tahun 2015 hingga saat ini masih sangat rendah.

Permendagri No.114 tahun 2014 tentang Pedoman Pembangunan Desa dikeluarkan pada tanggal 31 Desember 2014 untuk mengatur program dana desa yang mulai direalisasikan pada tahun 2015 .
Peraturan ini secara khusus mengatur mekanisme pembangunan desa mulai dari tahap perencanaan hingga tahap pengawasan. Dalam pasal 5 menyebutkan bahwa perencanaan pembangunan desa meliputi dua tahapan, yakni penyusunan dokumen Rencana Pembangunan Jangka Menengah (RPJMDes) dan Rencana Kerja Pemerintah Desa (RKPDes). RPJMDes merupakan program kerja pemerintah desa dalam jangka waktu 6 tahun yang disusun paling lambat 3 bulan setelah pelantikan kepala desa, sedangkan RKPDes adalah program kerja tahunan pemerintah desa yang disusun pada bulan juli tahun berjalan dengan merujuk pada RPJMDes. Pihakpihak yang dilibatkan dalam penyusunan RPJMDes maupun RKPDes adalah pemerintah desa, badan permusyawaratan desa, tokoh masyarakat, tokoh agama, tokoh adat, tokoh pendidikan, perwakilan kelompok tani, nelayan, perajin, perempuan, pemerhati dan perlindungan anak, masyarakat miskin, dan kelompok lainnya sesuai dengan kondisi aspek sosial dan budaya masyarakat.

Proses penyusunan RPJMDes di Desa Naran dilaksanakan pada tahun 2015, tiga tahun setelah pelantikan kepala desa. Dalam dokumen RPJMDes Desa Naran periode 2015-2021 dikatakan bahwa RPJMDes disusun melalui proses penggalian potensi dan masalah desa dengan menggunakan pendekatan menggagas masa depan desa (MMDD) dan penggalian gagasan (pegas) yang dilaksanakan di tingkat kelompok dan dusun. Adapun tujuan penyusunan RPJMDes adalah untuk mewujudkan pembangunan yang sesuai dengan kebutuhan masyarakat, menciptakan rasa memiliki terhadap program pembangunan, mengembangkan hasil-hasil pembangunan dan meningkatkan peran serta masyarakat dalam pembangunan desa (Dokumen RPJMDes Desa Naran, 2015). 
Mengacu pada hakekat dan tujuan penyusunan RPJMDes, partisipasi masyarakat merupakan hal yang perlu dibangun dan ditingkatkan dalam menyusun perencanaan pembangunan desa. Namun, peneliti menemukan bahwa masyarakat belum begitu dilibatkan dalam perencanaan yang dimaksud. Salah satu staf Desa Naran yang saat itu menangani pembuatan RPJMDes dan RKPDes hingga selesai mengatakan, RPJMDes dan RKPDes di Desa Naran disusun oleh pemerintah desa melalui musyawarah desa yang dihadiri oleh kepala dusun, RW, RT, BPD dan tokoh masyarakat sebagai perwakilan masyarakat. Tidak semua masyarakat diundang untuk mengikuti musyawarah desa karena seluruh staf pemerintahan Desa Naran belum memahami mekanisme penyusunan RPJMDes dan RKPDes. Proses penyusunan RPJMDes dan RKPDes sempat dibantu oleh orang yang dahulunya adalah fasilitator PNPM-MP, namun karena banyaknya desa yang ditangani, maka RPJMDes dan RKPDes yang dihasilkan menjadi tidak efisien karena data yang digunakan lebih banyak disalin dan dipindahkan (dicopy paste) dari data desa lain.

Kualitas sumber daya manusia (SDM) memegang peranan penting dalam perencanaan pembangunan desa, baik itu berkaitan dengan kapabilitas pemerintah desa maupun masyarakat secara luas (Wijaksono, 2013). Rendahnya kualitas SDM dapat menyebabkan proses maupun hasil perencanaan pembangunan tidak sesuai dengan kebutuhan masyarakat. Selain itu, keterbatasan waktu yang diberikan oleh pemerintah kabupaten merupakan faktor lainnya yang menyebabkan proses pembuatan RPJMDes dan RKPDes menjadi tidak efektif. Sinkronisasi waktu kerja antara pemerintah desa, pemerintah kabupaten dan pemerintah pusat perlu menjadi bahan pertimbangan dalam menyusun perencanaan pembangunan desa. Dengan adanya sinkronisasi kerja antar pemerintah di berbagai tingkatan, perencanaan pembangunan desa tidak akan dilakukan secara tergesa-gesa.

Pada tahun-tahun berikutnya sesudah tahun 2015, pemerintah desa hanya menyelenggarakan musyawarah desa dan musyawarah perencanaan pembangunan desa untuk menyusun RKPDes. Musyawarah desa dilaksanakan di kantor desa untuk menyusun prioritas usulan pembangunan sesuai dengan tingkatan urgensinya, sedangkan musrenbangdes diselenggarakan untuk menetapkan rancangan RKPDes menjadi Perdes RKPDes, sekaligus melihat kembali program-program yang tidak berada dalam wewenang pembiayaan dana desa untuk diusulkan ke tingkat kecamatan dan selanjutnya dibawa ke tingkat kabupaten.

Pada tanggal 21-22 Desember 2018, peneliti mengikuti pelatihan aparatur desa yang dilaksanakan di kantor Desa Naran. Materi yang dibawakan adalah tentang tahapan-tahapan dalam proses pelaksanaan pembangunan desa. Dari 9 staf desa yang hadir, tidak ada satupun yang memahami dengan baik proses pelaksanaan pembangunan desa. Sekretaris desa sebagai pimpinan sekretariat pun hanya mengetahui sebagian kecil dari keseluruhan proses pelaksanaan pembangunan desa, padahal tiga tahun telah berlalu sejak program dana desa dilaksanakan. Kurangnya sosialisasi terkait mekanisme perencanaan pembangunan dapat menjadi penyebab lainnya dari kondisi ini (Sagita, 2016).

Staf lainnya yang telah bekerja dari tahun 2015 hingga saat ini menjelaskan lebih lanjut bahwa RPJMDes dan RKPDes disusun berdasarkan musyawarah yang diikuti oleh kepala dusun, RW, RT, tokoh masyarakat dan BPD. Namun, kehadiran mereka menjadi simbolisasi belaka karena sebagian besar dari mereka tidak sanggup memberikan usul saran kepada pemerintah desa terkait program pembangunan yang akan dilaksanakan. 11 dari 12 informan mengatakan bahwa dari sekian banyak peserta yang hadir dalam musyawarah desa tahun 2015-2018, hanya terdapat 3-4 orang yang rutin memberikan usul saran kepada pemerintah desa ketika diberi kesempatan. 
Peserta yang lainnya cenderung menyetujui hal-hal yang dikemukakan oleh orang-orang tersebut.

Hasil observasi peneliti terhadap beberapa kegiatan yang dilaksanakan di kantor Desa Naran mendapatkan hasil yang lebih buruk dari pemaparan staf desa di atas. Pada tanggal 10 Desember 2018, peneliti mengikuti kegiatan musrenbangdes di Balai Desa Naran. Pada kesempatan pertama untuk bertanya setelah pembacaan rekomendasi tim verifikasi oleh sekretaris desa, dari 47 peserta yang hadir, tidak ada peserta yang bertanya ataupun memberikan usul saran. Pada kesempatan kedua setelah pembacaan matrix RKPDes 2019, hanya satu orang yang memberikan usul saran setelah dianjurkan berulang-ulang kali oleh moderator untuk memberikan tanggapan.

Tanggal 27 Desember 2018, peneliti kembali mengikuti kegiatan sosialisasi kesehatan ibu dan anak di Kantor Desa Naran. Ketika diberi kesempatan untuk bertanya setelah, dari 17 kader posyandu yang hadir tidak ada satu pun yang bertanya. Begitu pula dengan kegiatan Pembinaan Kesejahteraan Keluarga (PKK) yang dilaksanakan pada tanggal 28 Desember 2018. Dari 27 peserta yang hadir, hanya 1 orang yang memberikan usul saran, yakni ketua kader posyandu yang merangkap sebagai bendahara PKK. Meskipun kegiatan pelatihan aparatur desa, sosialisasi kesehatan ibu dan anak, dan pelayanan kesejahteraan keluarga bukan merupakan bagian dari perencanaan pembangunan desa, ketiga kegiatan tersebut merupakan pembanding untuk melihat seberapa jauh masyarakat Desa Naran, kepala dusun, RW, RT, dan tokoh masyarakat aktif dalam memberikan sumbangsih pemikiran yang bermanfaat bagi proses pengambilan keputusan.

\section{METODE PENELITIAN}

Studi kasus kualitatif terhadap perencanaan pembangunan desa ini dilakukan di Desa Naran Kecamatan Raimanuk Kabupaten Belu. Data diperoleh dari 12 informan yang diwawancarai dengan menggunakan teknik snowball sampling. Informan dalam penelitian ini terdiri dari mantan kepala desa periode 2012-2018, Penjabat desa, 4 orang staf desa, wakil ketua BPD sekaligus ketua TPK, 1 orang Kepala Dusun, 1 orang RW sekaligus mantan kepala dusun selama 49 tahun, 1 orang tokoh masyarakat, 1 orang masyarakat yang juga menjabat sebagai ketua kader posyandu dan 1 orang masyarakat yang jarang terlibat dalam perencanaan pembangunan desa.

Peneliti juga melakukan observasi secara langsung terhadap perencanaan pembangunan dan studi terhadap dokumen-dokumen perencanaan berupa surat undangan musyawarah, daftar hadir, notulen, RPJMDes dan RKPDes di Desa Naran. Data dianalisis dengan menggunakan teknik analisis pembuatan eksploratoris (Yin, 2015). Untuk memastikan keabsahan data, peneliti melakukan focus group discussion (FGD) sebanyak 1 kali dan konfirmabilitas temuan terhadap staf pemerintahan desa.

\section{HASIL DAN PEMBAHASAN}

4.1 Budaya "Mamfatin Ukunrai” Sebagai Paradoks Partisipasi Masyarakat Dalam Perencanaan Pembangunan Desa

Kecamatan Raimanuk adalah kecamatan terluas keempat di Kabupaten Belu setelah Kecamatan Tasifeto Barat, Tasifeto Timur dan Kakuluk Mesak. Jika dilihat dari kepadatan penduduknya, Kecamatan Raimanuk berada pada urutan keenam setelah Kecamatan Kota Aatambua, Tasifeto Barat, Tasifeto Timur, Atambua Selatan dan Atambua Barat. Namun, kecamatan ini memiliki jumlah fakir miskin jauh lebih besar di bandingkan dengan semua kecamatan yang ada. Kecamatan yang lain memiliki fakir miskin berkisar \pm 2500an namun Kecamatan Raimanuk memiliki 9.153 KK. Jika diurut berdasarkan tingkat kemiskinan terendah di Indonesia, maka sebanyak $1.951 \mathrm{KK}$ masih berada di bawah $10 \%$, 
terdapat $261 \mathrm{KK}$ berada diantara 11-20\%, $245 \mathrm{KK}$ berada di antara 21-30\%, $184 \mathrm{KK}$ berada di antara 31-40\%, selebihnya berada di atas tingkat kemiskinan terendah Indonesia (Badan Pusat Statistik, 2018b).

Letak kecamatan ini cukup jauh dari daerah ibukota, yakni berjarak 41,0 km. Di samping itu, akses menuju beberapa desa masih terbatas. Kehidupan masyarakatnya masih terikat kuat pada adat istiadat yang berlaku, meskipun sudah mulai terbiasa mengakses dan menggunakan teknologi. Tingkat pendidikan masyarakat masih tergolong rendah. Dari 14.605 jiwa, penduduk yang tidak pernah sekolah berjumlah 3.520 orang, masih SD berjumlah 3.198, tamat $\mathrm{SD} /$ sederajad berjumlah 3.931 orang, tamat $\mathrm{SMP} /$ sederajad berjumlah 988 orang, tamat SMA/sederajad berjumlah 722 orang, SM Kejuruan berjumlah 56 orang, DI-DIII berjumlah 81 orang, DIV-S1 berjumlah 57 orang, sedangkan S2-S3 belum ada. 2.052 lainnya tidak terkategorisasikan karena tidak terdapat dalam data (Badan Pusat Statistik, 2018a).

Desa Naran merupakan desa tradisional dengan jumlah penduduk terbanyak di Kecamatan Raimanuk, yakni 2.880 jiwa dengan jumlah rumah tangga sebanyak 630 rumah tangga. Selain memiliki jumlah penduduk yang banyak, pendidikan masyarakat juga masih tergolong rendah. Aksesibilitas penduduk terhadap sumber daya alam berupa air, sumber energi listrik masih cukup terbatas. Demikian pula dengan aksesibilitas jalan dari beberapa dusun yang terletak agak ke dalam dan tidak dilalui oleh jalan raya umum. Sebagian besar masyarakat bermata pencaharian sebagai petani. (Dokumen Perencanaan Hasil Musdus dan PKD TA 2017 Desa Naran Kecamatan Raimanuk). Atmojo, et al (2017) dalam penelitiannya menyebutkan bahwa dana desa dapat meningkatkan akuntabilitas pemerintah dan pemenuhan kebutuhan masyarakat sejauh masyarakat berpartisipasi secara aktif dalam pengelolaan dana desa.

Keaktifan masyarakat dalam berpartisipasi, terutama dalam perencanaan pembangunan dapat meningkatkan efektivitas dan efisiensi program-program pembangunan yang dihasilkan karena bagaimanapun, masyarakatlah yang paling tahu apa yang dibutuhkannya. Seperti yang dijelaskan sebelumnya, partisipasi masyarakat dalam perencanaan pembangunan di Desa Naran sangat rendah, baik itu dilihat dari tingkat kehadiran maupun jumlah masyarakat yang ikut memberikan sumbangsih pemikiran dalam proses pengambilan keputusan. Ketika dikaji lebih jauh, peneliti menemukan alasan lain di balik alasan-alasan yang nampak, yaitu budaya mamfatin ukunrai.

Kata mamfatin ukunrai berasal dari bahasa Tetun, dari kata mamfatin yang artinya urusan, pekerjaan, atau kebijakan dan ukunrai yang berarti pemimpin atau pemerintah. Dengan demikian, mamfatin ukunrai berarti urusan pemerintah, pekerjaan pemerintah atau kebijakan pemerintah. Budaya mamfatin ukunrai tidak merujuk pada adat istiadat yang diwariskan turun temurun secara sadar agar tetap lestari, namun lebih kepada suatu kebiasaan yang lahir dari kepercayaan masyarakat terhadap kebiasaan, yang telah mempengaruhi pola pikir dan tingkah laku masyarakat sedemikian rupa, sehingga partisipasi masyarakat dalam perencanaan pembangunan menjadi rendah.

Budaya mamfatin ukunrai merupakan suatu kebiasaan masyarakat yang cenderung memisahkan antara apa yang seharusnya menjadi urusan pemerintah dan apa yang seharusnya menjadi urusan masyarakat. Masyarakat memandang bahwa segala hal yang berkaitan dengan perencanaan pembangunan desa merupakan tugas dan tanggung jawab pemerintah desa, sedangkan masyarakat hanya sebagai pihak yang melaksanakan hasil keputusan yang telah ditetapkan. Salah satu staf desa menuturkan, peserta yang diundang untuk mengikuti musyawarah desa sering sekali menolak untuk hadir dengan alasan sibuk bekerja di kebun, di sawah ataupun di pasar. Namun mereka berjanji akan 
melaksanakan hasil keputusan musyawarah tersebut.

Ibu Maria (44 tahun), salah seorang warga masyarakat yang berhasil diwawancarai menyampaikan bahwa:

"Coba tanya mama Ika atau mama Siska soalnya dong yang lebih tahu soal desa punya supaya lebih jelas to, saya ni biasa ikut yang kader punya sa. Dong datang kasih tahu, kadang lewat telpon ma saya ada mau pi pasar, habis dong telpon ma se mak na hain se mak iha neba o. Hau te baruk, nanti mau buat apaapa baru sa yang buat sa" (Berkaitan dengan urusan desa, sebaiknya ditanyakan kepada ibu Ika atau ibu Siska (orang-orang yang biasa dipilih untuk mengikuti kegiatan musyawarah desa) karena saya jarang mengikuti kegiatan di desa. Meskipun telah diberitahu, saya harus ke pasar jadi siapa yang harus berada di sini dan siapa yang harus berada di sana. Saya malas, kalau berkaitan dengan pelaksanaan hasil keputusan musyawarah, saya akan melaksanakannya).

(Wawancara pada hari Seelasa, 19 November 2018). Bapak Dominikus (34 tahun), terhadap fenomena ini menjelaskan: "gambaran Desa Naran soal aktif atau tidak aktifnya itu tergambar dari para kepala dusun, RT, RW itu. Pada prinsipnya mereka masih menyetujui orang-orang yang vokal berbicara, tingkat pendidikannya lebih tinggi sehingga ketika mulai diforumkan segala sesuatu, orang berbicara yang lain dengan sendirinya iya. Budaya kita orang timur, kami itu sangat menghargai pimpinan. Bagi kami pimpinan itu orang yang tahu segalanya sehingga kalau bapa desa sudah berbicara, semua pasti ikut saja. Mungkin juga karena kendala bahasa indonesia, kita punya kepala dusun, RW, RT dong ini kan banyak yang SD. Bahkan ada yang tidak sekolah juga" (Partisipasi masyarakat Desa Naran direpresentasikan oleh partisipasi kepala dusun, RW dan RT. Meskipun demikian, mereka cenderung untuk ,menyetujui apa yang dikatakan oleh orang-orang yang biasanya aktif berbicara di kantor dan berpendidikan tinggi. Di samping itu, budaya orang timur yang sangat menghargai pimpinannya dan menganggap pimpinannya sebagai orang yang tahu segalanya membuat mereka cenderung diam dan mengikuti sesuai dengan apa yang dibicarakan oleh kepala desa. Ketidakmampuan untuk berbahasa Indonesia secara baik dan benar juga menjadi kendala dalam berpartisipasi, mengingat pendidikan para kepala dusun, RW dan RT hanya sebatas Sekolah Dasar (SD) bahkan ada yang tidak bersekolah).(Wawancara pada hari Selasa, 26 November 2018).

Hasil wawancara terhadap salah satu staf desa tersebut di atas, Ibu Maria dan Bapak Dominikus menunjukkan bahwa masyarakat sudah sedemikian rupa terpola dengan budaya mamfatin ukunrai sehingga mereka akan lebih memilih menjalankan rutinitas kesehariannya dibanding mengikuti musyawarah perencanaan pembangunan desa. Orangorang yang diandalkan untuk mengikuti musyawarah adalah orang-orang yang aktif berbicara (tokoh masyarakat), kepala dusun, RW dan RT. Namun, 'perwakilan 
substantif' ini ternyata belum mampu merepresentasikan kebutuhan masyarakat. Ibu Fransiska (39 tahun) mengatakan masyarakat Naran cenderung mempercayai orang-orang yang biasa berbicara dalam musyawarah sehingga apapun yang dibicarakan oleh orang-orang tersebut, yang lainnya akan setuju dan mengiyakan karena mereka percaya bahwa yang dikatakan orang-orang tersebut adalah yang terbaik untuk dusun. Dengan demikian, sistem perwakilan yang diterapkan di Desa Naran masih jauh dari sistem keterwakilan yang sesungguhnya. Untuk lebih jelasnya dapat dilihat pada tabel berikut :

Tabel 1.2. Rekapan Daftar Hadir Sesuai Jabatan dalam musdes 2017 dan 2018

\begin{tabular}{|c|c|c|c|c|c|c|}
\hline $\begin{array}{l}\mathbf{N} \\
\mathbf{0}\end{array}$ & $\begin{array}{c}\text { Jabat } \\
\text { an }\end{array}$ & $\begin{array}{l}\text { Jum } \\
\text { lah }\end{array}$ & $\begin{array}{c}\text { Ha } \\
\text { dir } \\
201 \\
7\end{array}$ & $\begin{array}{c}\% \\
\text { Ha } \\
\text { dir } \\
201 \\
7\end{array}$ & $\begin{array}{c}\text { Ha } \\
\text { dir } \\
201 \\
8\end{array}$ & $\begin{array}{c}\% \\
\text { Ha } \\
\text { dir } \\
201 \\
8\end{array}$ \\
\hline 1 & $\begin{array}{l}\text { Staf } \\
\text { Desa }\end{array}$ & 12 & 5 & $\begin{array}{l}42 \\
\%\end{array}$ & 4 & $\begin{array}{l}33 \\
\%\end{array}$ \\
\hline 2 & BPD & 7 & 3 & $\begin{array}{l}43 \\
\%\end{array}$ & 3 & $\begin{array}{l}43 \\
\%\end{array}$ \\
\hline 3 & $\begin{array}{l}\text { Kepal } \\
\text { a } \\
\text { Dusun }\end{array}$ & 12 & 5 & $\begin{array}{l}42 \\
\%\end{array}$ & 6 & $\begin{array}{l}50 \\
\%\end{array}$ \\
\hline 4 & RW & 12 & 5 & $\begin{array}{l}42 \\
\%\end{array}$ & 6 & $\begin{array}{l}50 \\
\%\end{array}$ \\
\hline 5 & RT & 24 & 15 & $\begin{array}{l}62 \\
\%\end{array}$ & 8 & $\begin{array}{l}33 \\
\%\end{array}$ \\
\hline 6 & Kader & 35 & 2 & $\begin{array}{l}5 \\
\%\end{array}$ & 2 & $\begin{array}{l}5 \\
\%\end{array}$ \\
\hline 7 & $\begin{array}{l}\text { Tokoh } \\
\text { Pendi } \\
\text { dik }\end{array}$ & \pm 30 & 3 & $\begin{array}{l}10 \\
\%\end{array}$ & 1 & $\begin{array}{l}3 \\
\%\end{array}$ \\
\hline 8 & $\begin{array}{l}\text { Tokoh } \\
\text { Masya } \\
\text { rakat }\end{array}$ & \pm 30 & 4 & $\begin{array}{l}13 \\
\%\end{array}$ & 2 & $\begin{array}{c}6 \\
\%\end{array}$ \\
\hline 9 & $\begin{array}{l}\text { Masya } \\
\text { rakat }\end{array}$ & $\begin{array}{c} \pm \\
280 \\
0 \\
\end{array}$ & 3 & $\begin{array}{c}0.1 \\
\%\end{array}$ & 2 & $\begin{array}{c}0.0 \\
7 \\
\%\end{array}$ \\
\hline & $\begin{array}{l}\text { MLAH } \\
\text { OTAL }\end{array}$ & $\begin{array}{c} \pm \\
296 \\
2\end{array}$ & 45 & & 34 & \\
\hline
\end{tabular}

Sumber : Daftar hadir musdes 2017 dan foto kegiatan musdes 2018
Tabel 1.2 menunjukkan bahwa dari keseluruhan staf pemerintahan desa yang diundang pada tahun 2017, hanya RT yang kehadirannya mencapai $50 \%$, sedangkan pada musdes tahun 2018, hanya kepala dusun dan RW yang kehadirannya mencapai 50\%. Jika dilihat dari kehadiran kader, tokoh pendidik, tokoh masyarakat dan masyarakat, selama dua tahun berturut-turut kehadirannya tidak mencapai $15 \%$. Hal ini dikarenakan tidak semua kader, tokoh pendidikan, tokoh masyarakat dan masyarakat diundang untuk menghadiri kegiatan musdes tetapi lebih kepada orang-orang tertentu yang dipilih oleh pemerintah desa. Pada dasarnya, orang-orang yang dipilih merupakan orang-orang yang dituakan ataupun yang aktif berpendapat dalam kegiatan musyawarah. Hasil wawancara terhadap sebagian besar informan dan hasil pengamatan peneliti terhadap kegiatankegiatan yang pernah peneliti ikuti menunjukkan bahwa dari 55 orang BPD, kepala dusun, RT dan RW yang sering mengikuti kegiatan musyawarah, hanya terdapat 3-4 orang yang biasa mengemukakan pendapatnya atau sekedar bertanya mengenai program perencanaan pembangunan yang akan dilaksanakan. Selebihnya cenderung mengiyakan apa yang dikatakan oleh orang-orang yang aktif berbicara dan pemerintahan desa.

Pada tahun 2018, pemerintah mencoba menerapkan sistem perencanaan pembangunan desa yang lebih transparan dengan melaksanakan musyawarah di tingkat dusun secara umum, namun tabel 1.1 memperlihatkan bahwa dari 12 dusun yang ada, hanya 2 dusun yang tingkat kehadirannya mencapai 50\%. Bahkan salah satu dusun sempat diundurkan jadwal musdusnya karena tidak ada masyarakat yang hadir pada hari yang ditentukan. Menurut hasil wawancara terhadap beberapa informan, penyelenggaran musdus tahun 2018 dilakukan dengan cara menggabungkan dua dusun dalam sehari sehingga tim penyusun dipecah menjadi dua, apabila masing-masing dusun diselenggarakan di tempat yang berbeda. Terdapat 4 dusun yang musdusnya 
diselenggarakan secara bersamaan, yakni Dusun Tukunu dan Kota Ikun, Subaru dan Wekrame. Hal ini dilakukan karena adanya desakan dari pemerintah daerah untuk segera mengkonsultasikan RKPDes. Peneliti menilai bahwa hal-hal di atas terjadi karena pelaksanaan musdus baru dilakukan untuk pertama kalinya di Desa Naran. Disamping itu, kurangnya pemahaman staf pemerintahan dan masyarakat desa terkait mekanisme pelaksanaan musdus merupakan kendala lainnya. Apabila mereka memahami dengan baik maka musdus, musdes dan musrenbangdes akan dilakukan jauh sebelum adanya desakan dari pemerintah kabupaten sehingga pelaksanaan kegiatannya tidak dilakukan dengan tergesa-gesa.

Sejauh pengamatan peneliti, penyelenggara musyawarah ataupun pemberi sosialisasi selalu memberikan kesempatan untuk bertanya atupun memberikan saran dalam kegiatankegiatan yang diselenggarakan namun masyarakat enggan bertanya. Hal ini tentunya menjadi dilema bagi pemerintah Desa Naran, karena ketentuan mengharuskan masyarakat berpartisipasi secara baik dan benar namun masyarakat enggan untuk berpartisipasi dan lebih memilih menjadi pihak yang melaksanakan hasil keputusan dibandingkan dengan ikut mempengaruhi hasil perencanaan pembangunan. Fando (27 tahun), salah satu staf desa yang mengikuti hampir seluruh musyawarah dusun pada tahun 2018 mengatakan:

"waktu musdus ni masyarakat dong hadir, tidak semua tapi lumayan. 20-an lebih, ada yang lebih banyak lagi model ke di SKB dgn Amea... kebanyakan yang omong ni kepala dusun, terus ada tambahan dari tokoh masyarakat yang biasa omong itu. Kalo yang lain ya begitulah"(Masyarakat yang hadir dalam kegiatan musdus berjumlah 20-an orang atau lebih, seperti di SKB dan
Amea... Kepala dusun merupakan pihak yang paling dominan berbicara ketika musdus dan beberapa orang tokoh masyarakat yang biasa berbicara).(Wawancara pada hari Senin, 12 November 2018).

Selain hasil wawancara terhadap Fando, peneliti juga sempat mewawancarai Bapak Agus (63 tahun), salah satu RW yang sebelumnya menjabat sebagai kepala dusun selama 49 tahun. Beliau mengatakan bahwa dalam musyawarah dusun yang dilaksanakan di dusunnya, beliau adalah satu-satunya orang yang memberikan usulsaran kepada pemerintah desa terkait pembangunan saluran drainase. Peneliti menemukan bahwa meskipun tidak dapat berbicara bahasa Indonesia dengan benar, beliau cukup antusias dalam memberikan sumbangsih pemikiran. Dalam musrenbangdes yang sempat peneliti ikuti pun beliau adalah satu-satunya orang yang memberikan usulan dari 49 peserta yang hadir. Meskipun sempat menjawab "saya tidak tahu karena saya orang bodok" ketika ditanya soal program apa yang diusulkan dari masalah yang diceritakannya, keinginan Bapak Agus untuk berpartisipasi sangat tinggi. Berdasarkan pengamatan peneliti terhadap Bapak Agus, peneliti berkesimpulan bahwa tidak dapat berbahasa Indonesia dengan baik dan benar sebenarnya tidak menjadi kendala dalam berpartisipasi, tetapi mental masyarakat yang sudah terpola dengan budaya mamfatin ukunrai.

Budaya mamfatin ukunrai tidak hanya terdapat pada masyarakat yang tidak mempunyai jabatan dalam struktur pemerintahan desa, tetapi juga pada sebagian besar unsur-unsur pemerintatahan desa, seperti BPD, kepala dusun, RW, dan RT. Maka untuk memastikan musyawarah perencanaan berjalan sebagaimana mestinya, pemerintah desa mendominasi perencanaan pembangunan desa dengan lebih banyak mengarahkan masyarakat untuk mempertimbangkan program pembangunan mana yang bersifat mendesak dan harus segera dilakukan, 
mengajak masyarakat untuk mengemukakan pendapat atau bertanya, atau sekedar mengajak masyarakat untuk bersikap lebih santai dalam musyawarah yang diselenggarakan. Di satu sisi, ketentuan mengharuskan masyarakat berpartisipasi secara aktif dalam perencanaan pembangunan, namun budaya mamfatin ukunrai menyebabkan partisipasi masyarakat menjadi rendah sehingga pemerintah dipaksa untuk mengambil alih dalam setiap perencanaan yang dilakukan. Alyas (2015) mengemukakan bahwa pemimpin dapat meningkatkan partisipasi masyarakat menggunakan cara persuasif ataupun dengan mengakomodasi partisipasi masyarakat. Sejauh ini, peneliti melihat bahwa pemerintah Desa Naran pun telah menempuh cara-cara persuasif dan mengakomodasi partisipasi masyarakat dengan menyelenggarakan musyawarah dusun. Akan tetapi, jumlah masyarakat yang hadir maupun yang memberikan sumbangsih pemikiran masih sangat rendah.

Kondisi partisipasi masyarakat di Desa Naran saat ini tidak dapat digolongkan ke dalam salah satu tangga partisipasi Arnstein, hal ini dikarenakan masyarakat enggan untuk berpartisipasi secara langsung dalam perencanaan pembangunan, dan lebih memilih memberikan hak kepada BPD, tokoh masyarakat yang aktif berbicara, kepala dusun, RW dan RT untuk berunding dalam proses pengambilan keputusan, sedangkan pihak pemerintah tidak menunjuk perwakilan tertentu untuk mengakses proses pengambilan keputusan. Masyarakat diberikan kewenangan untuk berpartisipasi namun mereka cenderung memilih untuk mempercayakannya kepada 'perwakilan' nya. Hal ini membuat kondisi masyarakat Desa Naran berada di antara tingkat placation dan delegated power namun tidak dapat digolongkan ke dalam salah satunya.

Budaya mamfatin ukunrai erat kaitannya dengan lebarnya jarak kekuasaan antara pemerintah dan masyarakat Desa Naran, yang telah berlangsung selama berpuluh-puluh tahun. Pada zaman dahulu, apabila masyarakat tidak menghormati pimpinannya maka masyarakat tersebut akan didenda secara adat. Demikian pula kondisi saat ini, meskipun tidak seketat dahulu. Dalam acara adat ataupun pestapesta yang diselenggarakan, pemerintah dengan jabatan tertinggi biasanya menduduki kursi paling depan. Hidangan acara pun biasanya disiapkan tersendiri dan lebih istimewa dibandingkan sebelumnya. Meskipun pemerintah yang bersangkutan tidak memintanya, masyarakat dengan sendirinya akan melakukannya untuk menunjukkan tanda penghormatan dan penghargaannya terhadap pemerintah. Orientasi kehidupan masyarakat yang lebih bersifat jangka pendek membuat masyarakat masih berpegang teguh pada tradisi, kebiasaan, nilai dan norma yang berlaku di dalam masyarakat, baik itu yang diwariskan secara langsung maupun tidak langsung. Kebiasaan sangat menghargai pemerintah tanpa disadari menciptakan jarak tak kelihatan antara pemerintah dan masyarakat, sehingga membuat masyarakat enggan untuk berpartisipasi. Selain tingginya jarak kekuasaan, rendahnya kualitas sumber daya manusia, kurangnya sosialisasi pemerintah kabupaten terhadap pemerintah desa terkait mekanisme pelaksanaan pembangunan desa yang baik dan benar, serta kurangnya kesadaran masyarakat merupakan faktor lainnya yang turut mendukung dan mendorong budaya mamfatin ukunrai.

\section{KESIMPULAN}

Komunikasi Pembangunan dalam Budaya masyarakat desa sangat mempengaruhi pola pikir dan tingkah laku masyarakat, termasuk dalam perencanaan pembangunan desa. Budaya mamfatin ukunrai bukanlah satu-satunya penyebab partisipasi masyarakat menjadi sangat rendah dalam perencanaan pembangunan di Desa Naran, namun faktor ini adalah faktor yang paling dominan karena hampir sebagian besar masyarakat masih memiliki pola pikir dan pola tingkah laku budaya mamfatin ukunrai. Jarak kekuasaan yang lebar antara pemerintah dan masyarakat, 
rendahnya kualitas sumber daya manusia (aparatur pemerintahan desa dan masyarakat desa), kurangnya kapabilitas perwakilan yang katanya menjadi andalan dan kepercayaan masyarakat, serta masih dan rendahnya tata kelola pemerintahan desa merupakan faktor-faktor lainnya yang pada akhirnya turut berkontribusi dalam mendorong budaya mamfatin ukunrai dalam perencanaan pembangunan desa.

\section{REFERENSI}

Al-Kautsari, M. M. (2017). Model Transisi Peningkatan Partisipasi Masyarakat Desa. Jurnal Pemberdayaan Masyarakat, 1(1), 151-159. Retrieved from http://journal.uinsuka.ac.id/dakwah/JPMI

Alyas. (2015). Lurah dan Partisipasi Masyarakat dalam Pembangunan di Kelurahan Cabenge Kecamatan Lilirilau Kabupaten Soppeng. Sosiohumaniora, 17(1), 84-96.

Atmojo, Eko, M., Fridayani, H. D., Kasiwi, A. N., \& Pratama, M. A. (2017). Efektivitas dana desa untuk pengembangan potensi ekonomi berbasis partisipasi masyarakat di Desa Bangunjiwo Muhammad Eko Atmojo , Helen Dian Fridayani, Aulia Nur Kasiwi, Mardha Adhi Pratama Program Studi Ilmu Pemerintahan , FISIP Univeristas Muhammadiya. ARIST Sosial Politik Humaniora, 5(1), 126-140.

Badan Pusat Statistik, K. B. (2018a). Kabupaten Belu dalam Angka 2018. Katalog.

Badan Pusat Statistik, K. B. (2018b). Statistik Kesejahteraan Rakyat Kabupaten Belu Tahun 2018. Katalog.

Defina. (2012). The Community Participation and Socialization in Empowering Program ( PPMK ) at Klender Village. Penyuluhan, 9(2).
Fitriani, E., Selinaswati, \& Mardiah, D. (2017). Partisipasi Asyarakat Dalam Pembangunan Ekowisata Sungai Pinang. Socius, 4(1), 83-96.

Marzuki, A. (2009). A Review on Public Participation in Environmental Impact Assessment in Malaysia. Theoretical and Empirical Research in Urban Management, 4(3), 126136. https://doi.org/10.5379/urbaniizziv-en-2010-21-02-006

Mbeche, R. (2017). Climbing The Ladder of Participation Symbolic or Subtantive Representation in Preparing Uganda for REDD+. Conservation and Society, 15(4), 426-438.

https://doi.org/10.4103/cs.cs

Ompusunggu, V. (2017). Peranan Partisipasi Masyarakat Dalam Perencanaan Pembangunan Desa. Jurnal Sektor Publik, 10(1), 95-102. Retrieved from http://pep3d.jabarprov.go.id/index.ph $\mathrm{p} /$ berita/artikel/77-perananpartisipasi-masyarakat-dalamperencanaan-pembangunan-desa

Rumensten, I. (2012). Model Ideal Partisipasi Masyarakat Dalam Pembentukan Peraturan Daerah. Jurnal Dinamika Hukum, 12(1), 135148.

https://doi.org/10.1017/CBO9781107 415324.004

Sagita, N. I. (2016). Partisipasi Warga Masyarakat Dalam Penilaian Kinerja Kecamatan Di Kota Bandung. CosmoGov, 2(2), 308-329. https://doi.org/10.24198/cosmogov.v 2i2.10009

Wijaksono, S. (2013). Pengaruh Lama Tinggal Terhadap Tingkat Partisipasi Masyaraka Dalam Pengelolaan Lingkungan Permukiman. Journal ComTech BINUS, 4(1), 24-32.

Yin, Robert K. 2015. Studi Kasus : Desain dan Metode. Jakarta : Raja Grafindo Persada 
